\title{
A SURVEY OF BELIEFS AND PRIORITIES ABOUT ACCESS TO JUSTICE OF FAMILY LAW: THE SEARCH FOR A MULTIDISCIPLINARY PERSPECTIVE*
}

\author{
Peter Salem** \\ and Michael Saini***
}

\begin{abstract}
Within the last decade, the term "Access to Justice" has grown in popularity among legal commentators, scholars, family justice reformers, government policy makers, and the media. But with all of this new attention, there remains no common understanding or definition of Access to Justice and its potential implications for children and families in domestic relation courts. The purpose of this crosssectional online survey was to explore the meaning of Access to Justice according to legal, mental health, and dispute resolution professionals in various countries. The sample included 442 respondents (e.g., judges, lawyers, custody evaluators, mediators, family court services, court administrators, parent educators, etc.) from seven countries. Of the total respondents, 398 participants completed the survey (response rate of ninety percent). The majority of participants defined access to justice as the ability of disputants to seek and obtain a remedy through formal (e.g., the courts) or informal (e.g., mediation) institutions and services for resolving disputes. Noteworthy differences were reported, however, between the views of legal and mental health professionals, where the latter most likely viewed Access to Justice as a legal issue, while the former focused on alternative approaches outside of the legal system to resolve family disputes. Implications for family court reforms are discussed.

* The Authors wish to thank the AFCC Task Force on Access to Family Court Services for support, direction and leadership on this project. Thanks also to Charlene Depner, John Lande, and Timothy Hedeen for their helpful comments on the survey. Finally, thanks to Kelly Browe Olson and Stacey Platt for the insightful comments on earlier drafts of this Article.

** Executive Director, Association of Family and Conciliation Courts. The views expressed in this article are those of the co-author and not of the Association of Family and Conciliation Courts.

*** Associate Professor, Factor-Inwentash Faculty of Social Work, University of Toronto.
\end{abstract}




\section{INTRODUCTION}

"Access to Justice" is one of the most pressing issues confronting today's legal system. Over the last decade, countless task forces, initiatives, and commissions have taken on the issue, resulting in a myriad of government reports, legal commentaries, research studies, and media reports. ${ }^{1}$ Of particular concern are the unmet legal needs of children and families in the family court system, ${ }^{2}$ and with good reason. Free legal representation in family law matters is generally not available to lower income people in the United States, with the exception, in some areas, of matters involving intimate partner violence. ${ }^{3}$ There has also been a decline in recent years in accessible and responsive court services that assist families in resolving disputes. ${ }^{4}$ Widespread budget cuts have severely limited the availability of court staff to work with families in conflict. ${ }^{5}$ Due to the growing number of self-represented litigants, ${ }^{6}$ the increased procedural requirements by some courts, and an increase in the volume and complexity of matters before the courts, Gorham-Oscilowski notes that public funding for family court ser-

1 See Task Force on Access to Family Justice, Report of the Access to Family Justice Task Force (2009) [hereinafter Access to Justice Task Force]; Erin Shaw, Family Justice Reform: A Review of Reports and Initiatives (2012) [hereinafter Family Justice Reform]; Jean-Marc Fournier, Justice Access Plan (2011) [hereinafter Justice Access Plan]; Manitoba Bar Association, Town Hall Meetings on Access to Justice: Report and Summary (2011); Maryland Access to Justice Commission, Interim Report \& Recommendations (2009); Lorne Sossin \& Kent Roach, Access to Justice and Beyond, 60 U. Toronto L.J. 373 (2010); The Supreme Court of Ohio, Report and Recommendations of The Supreme Court of Ohio Task Force on Access to Justice (2015).

2 The family court system discussed in this paper is specific to domestic cases, child custody cases, and separation and divorce cases. These are distinguished from dependency and child protection family courts.

3 John M. Greacen, Self-Represented Litigants, The Courts, and the Legal Profession: Myths and Realities, 52 FAM. CT. Rev. 662, 663 (2014).

4 Access to Justice TAsk Force, supra note 1; A. Currie, Justiciable Problems and Access to Justice in Canada (Nov. 2007) (unpublished) (paper presented to the Osgoode Hall Roundtable on Legal Aid); Jonathan D. Glater, A Broad View of Access, 39 Loy. L.A. L. REv. 759 (2006).

5 Peter Salem, The Emergence of Triage in Family Court Services: The Beginning of the End for Mandatory Mediation?, 47 FAM. CT. REV. 371 (2009).

6 The statistics range from sixty to eighty percent of all litigants. This data is cited from an interview with Julie Macfarlane. See CBC News, Law prof finds 60-80\% of people don't use lawyers, CBC NEws (Jun. 4, 2012, 9:46 AM), http:/www.cbc.ca/news/canada/windsor/law-proffinds-60-80-of-people-don-t-use-lawyers-1.1219913. 
vices does not meet the needs of all children and their families within the court system. ${ }^{7}$

This state of affairs has created a stark dichotomy in our family courts between the wealthy and the poor. There are litigants with abundant resources who engage interdisciplinary teams of professionals to help them navigate the system. Some use a collaborative approach, engaging two lawyers (one on each side) along with additional mental health coaches, child specialists, and financial specialists, as needed. Others, in a more adversarial context, may hire multiple mental health and financial consultants to help them litigate their case. In contrast, many more parents lack the financial means to obtain even the most basic services necessary to address critical legal, mental health, and dispute resolution issues impacting their family.

Barriers to justice have resulted in the widespread perception that interaction with family courts is largely a frustrating, time-consuming, and expensive experience. ${ }^{8}$ Significant delays and backlogs within the family court system inhibit a litigant's ability to access services in a timely and cost-efficient manner, ${ }^{9}$ and this situation may be exacerbated for those without legal representation. Indeed, family court professionals who responded to this survey indicated that even though they perceived improved access to the courts in recent years, they believed that public trust and confidence in the courts have worsened during the same time.

There is widespread agreement on the need to create greater and more effective access to the family court system, but a lack of consensus about the potential solutions with many unanswered questions. What are the most desirable outcomes in a family law matter? Will legal representation for more clients provide the path to these outcomes? Do we ask too much of self-represented litigants? Can case management initiatives or dispute resolution programs solve the problem? How can efficiencies be maximized while maintaining due process and protecting our most vulnerable citizens? Where do we place our priorities for resources given the paucity of funding? Due to the inherently interdisciplinary nature of family law and the various viewpoints about how best to solve the

7 Ursula Gorham-Oscilowski, “It's Not Just All About The Technology": Understanding The Role Of Statewide Legal Information Websites In Expanding Access To Justice In The United States (2015).

8 Arinola Akinbobola \& Michael Saini, Barriers to Access to Justice: A Parent's Perspective (2015) (Conference paper from 52nd Annual Conference of the Association of Family and Conciliation Courts at New Orleans, LA).

9 Sossin, supra note 1. 
problems of access, it is critical for the field to grapple with these questions and to develop a common framework for addressing access to justice.

\section{A. Multifarious Definitions of Access to Justice}

The concept of access to justice emerged in the late $1970 \mathrm{~s}^{10}$ and initially focused on legal aid funding issues. ${ }^{11}$ There has been increased attention to non-legal approaches (e.g., courtside services, parent education, mediation, parenting coordination) in the past decade, but there remains a lack of consensus among legal and non-legal stakeholders about the reasons for the current barriers to access, and how best to approach unmet needs of litigants in the courts. " "To take only the most obvious example, the organized bar has a much stronger economic interest in promoting lawyers' services than in promoting research and policies that support greater reliance on qualified non-lawyers and procedural simplification."13 That said, there seems little question that lack of legal representation is the most pervasive barrier, particularly for those without substantial financial resources. According to Greacen, "most SRLs (self-represented litigants) represent themselves because they have no realistic alternative-free legal services are not available to them if they are poor; private representation is not affordable if they are of modest means."14

The ambiguity surrounding the term access to justice creates challenges in developing workable solutions to meet the needs of litigants. ${ }^{15}$ Mixed perceptions remain about the responsibility of various stakeholders in administering access to justice; whether access to justice equals access to a lawyer, ${ }^{16}$ whether the concept is limited to fair legal processes; and what role, if any, non-legal professionals should play. Furthermore, even if it were possible to pro-

10 Marc Galanter, Access to Justice in a World of Expanding Social Capability, 37 FordHAM URB. L.J. 115 (2010).

11 Richard Zorza, An Overview of Self-Represented Litigation Innovation, Its Impact, and an Approach for the Future: An Invitation to Dialogue, 43 FAM. L.Q. 519 (2009).

12 Gorham-Oscilowski, supra note 7.

13 Deborah L. Rhode, Access to Justice: An Agenda for Legal Education and Research, 62 J. LEgAL Educ. 531, 533 (2013).

14 Greacen, supra note 3, at 664.

15 Gorham-Oscilowski, supra note 7; Rhode, supra note 13; Michael J. Wolf, Collaborative Technology Improves Access to Justice, 5 N.Y.U. J. Legis. \& Pub. PoL'y 759 (2012).

16 Gorham-Oscilowski, supra note 7. 
vide legal representation to everyone, it is not clear that a more effective system would result. Therefore, instead of a common road map for addressing unmet needs of families in the justice system, access to justice has become a blanket term used to describe a wide range of approaches that are generally aimed at legal reform. Some approaches focus narrowly on better equipping litigants with legal representation, information, advice, or facilitated access to the court (e.g., self-help centers, unbundled legal services, parent information programs, or informal domestic relation trials). Other approaches are broader, incorporating case management initiatives in family court service agencies, ${ }^{17}$ online educational programs for parents, ${ }^{18}$ or dispute resolution processes. More recently, the focus seems to be shifting to the consideration of the differential and complementary nature of many of these efforts ${ }^{19}$ in an attempt to coordinate the various initiatives, reduce the burden on legal services providers, and differentiate services based on the greatest need. ${ }^{20}$

Identifying common ground on the meaning of access to justice is vital to identifying solutions that address the unmet needs of family justice system users. Importantly, a more inclusive framework is also consistent with the interdisciplinary nature of family law and the professionals that work with families to resolve their conflicts.

\section{Purpose}

We believe that access to justice in the family law context is best achieved by convening interdisciplinary stakeholders to address issues that impact children and families. It is therefore important to understand those stakeholders' views to better identify common ground. The ability of the stakeholders to work together, however, may be hampered by their differing interests and viewpoints. A lack of consensus about access to justice may result in

17 Peter Salem et al., Triaging Family Court Services: The Connecticut Judicial Branch's Family Civil Intake Screen, 27 PACE L. REV. 741 (2007).

18 Peter Salem et al., Taking Stock of Parent Education in the Family Courts: Envisioning a Public Health Approach, 51 FAм. Cт. Rev. 131 (2013).

19 Russell Engler, The Toughest Nut: Handling Cases Pitting Unrepresented Litigants Against Represented Ones, 62 Juv. \& FAM. CT. J. 10 (2011).

20 Gorham-Oscilowski, supra note 7; Richard Zorza, Some First Thoughts on Court Simplification: The Key to Civil Access and Justice Transformation, 61 Drake L. Rev. 845 (2013). 
supporting different research and policy priorities. ${ }^{21}$ The purpose of this survey is to explore the views, beliefs, and priorities of legal, mental health, and dispute resolution professionals regarding access to justice, and to explore their perspectives on the types of services that have been put in place to address the existing problem.

This study is important because it responds to the calls for empirical evidence to examine the process and outcomes of access to justice initiatives. ${ }^{22}$ The absence of empirical evidence limits sound resource allocation to access to justice initiatives. ${ }^{23}$ The results of this survey have the potential to better inform the coordination and implementation of initiatives by identifying common beliefs and priorities on which important access to justice decisions may be based.

\section{Methods}

This cross-sectional study used an electronic survey as the method for data collection. The online survey allowed for the distribution of the survey to a large number of potential participants within a short period of time. As the electronic survey was broadly circulated, participants were recruited from both rural and urban areas. The survey also collected open-ended responses from participants, which allowed for an in-depth analysis of the experiences of legal and mental health professionals.

\section{A. Sampling}

Purposive sampling was used. Recruited participants included lawyers, judges, evaluators, dispute resolution professionals, court administrators, and mental health professionals who provide ser-

21 Gorham-Oscilowski, supra note 7.

22 Rachel Birnbaum \& Nicholas Bala, Views of Ontario Lawyers on Family Litigants Without Representation, 65 U.N. Brunswick L.J. 99 (2012); Rhode, supra note 13; Linda F. Smith \& Barry Stratford, DIY in Family Law: A Case Study of a Brief Advice Clinic for Pro Se Litigants, 14 J. Law \& Fam. Stud. 167 (2012); Jessica Steinberg, In Pursuit of Justice? Case Outcomes and the Delivery of Unbundled Legal Services, 18 Geo. J. on Poverty L. \& Pol'y 453 (2011).

23 Gary Blasi, Deborah L. Rhode's Access to Justice: How Much Access? How Much Justice?, 73 Fordham L. Rev. 865 (2004); Russell Engler, Connecting Self-Representation to Civil Gideon: What Existing Data Reveal About When Counsel is Most Needed, 37 Fordham Urb. L.J. 37 (2009); GORHAM-OscilowsKi, supra note 7. 
vices in both the public and private sectors to families involved in family law disputes. Recruitment occurred by circulating the link to the online survey. The link was distributed to members of the Association of Family and Conciliation Courts, the International Association of Court Administrators, and the National Council of Juvenile and Family Court Judges.

\section{B. Data Collection}

The electronic survey was created using the software "Fluid Survey," an online Canadian counterpart to the U.S. based "Survey Monkey." This software uses security technology such as firewalls and encryption to ensure the protection of data. The survey consisted of thirty-three questions and took approximately thirty minutes to complete. The project was approved by the Ethics Review Board at the University of Toronto.

\section{Data Analysis}

Upon participants' completion of the survey, the survey was exported from Fluid Survey into the statistical software "SPSS" (Version 23) for analysis. Frequency data as well as bi-variate analyses (chi-square, t-test, ANOVA) were performed. Means and standard deviations are reported in the tables. All assumptions for normal distribution and cell counts were analyzed for each variable included in the analyses. Qualitative data (open-ended questions) were thematically analyzed with connections to the original survey questions.

\section{Results}

A total of 442 participants responded to the survey $(68.5 \%$ female and $31.5 \%$ male), and 398 included completed responses to all questions (90\% completion rate). Professional disciplines included: lawyers (attorneys, lawyers) (25.5\%), judges (judges, referees and magistrates, court commissioners) (16.8\%), evaluators (private evaluators, court-based evaluators, court assessors) $(16.8 \%)$, dispute resolution professionals (mediators, parenting coordinators, conciliators) $(12.9 \%)$, administrators (court adminis- 
trators, program managers) $(9.2 \%)$, mental health professionals (therapist, parenting coach, parent educator, supervised access coordinator) (7.6\%), and others (e.g., academics, advocates, etc.) $(11.3 \%)$. A slight majority of respondents stated that they worked in private for-profit settings $(52.1 \%)$, and just over one-third $(35.4 \%)$ of the participants worked in a public or court-connected setting. About $9 \%$ worked in private not for profit settings, and $3.7 \%$ stated that they worked in other settings.

Respondents were by and large experienced in family law issues. Across primary areas of professional practice, the majority of respondents were over the age of fifty $(71.4 \%)$, devoted $80-100 \%$ of their practice to family law matters $(58.3 \%)$, had worked in the family law sector for more than sixteen years $(61.5 \%)$ in large urban areas (locations with populations over 200,000) (54.6\%); $23.6 \%$ stated that they practiced in mid sized urban areas $(50,000$ to 199,999 ), $7.6 \%$ in small urban places (under 59,999 ), and $10 \%$ of participants stated that they practiced in rural areas.

\section{A. Definition of Access to Justice}

For the purpose of this study, access to justice was defined broadly, beyond legal services and including dispute resolution. Respondents were provided with the following definition of access to justice: "[t]he ability of disputants to seek and obtain a remedy through formal (e.g., the courts) or informal (e.g., mediation) institutions and services for resolving disputes." There was substantial agreement with this definition with $87.6 \%$ of respondents indicating that it accurately described access to justice. Agreement with the definition was not correlated to the respondent's primary area of practice, whether they worked in a legal, mental health, or dispute resolution setting, or whether they worked in the private or public sector. No difference was found based on age of the participants, gender, years of practice in family law matters, or based on the size of their community. One notable difference was that participants from the United States reported higher agreement with the proposed definition than Canada, Australia, and other countries $\left(\mathrm{X}^{2}(3, \mathrm{~N}=348)=12.738, \mathrm{p}=.00\right)$. Those who did not agree with the definition $(12.4 \%)$ provided several alternative definitions that affirm the existence of the disparate views noted above. ${ }^{24}$ The

24 Note: One respondent terminated the completion of the survey and wrote to the authors indicating that the survey itself had little to do with Access to Justice. 
most common alternate approach emphasized the differences between access and justice. As one stated, "Courts are a court of law, not a court of justice." Another noted: "Access to the court is exactly what it says ... access to the court. Access to justice is an entirely different matter." Similarly, another stated, "Justice is a product of law, both statutory and judge made, and can only be achieved in a court room where rights and obligations are determined. In court, a party gets what they are entitled to or notthere is no middle ground."

Contrarily, others argued a greater emphasis should be given to "the therapeutic, social and other services necessary to support a family through the restructuring entailed by separation. Justice isn't just a legal issue in family law; they are all intertwined in produc[ing] just results." Respondents who commented that the focus on court-related remedies was too limiting, pointed out that "procedural fairness and the psychological experience of the process is important too." Others stated that the definition should also include "timely, efficiently and cost effectively." Another noted, "[a]ccess to [j]ustice as the ability of disputants to seek and obtain a remedy through a range of services for resolving disputes: education - therapeutic - mediation - Courts."

Some respondents emphasized the current barriers for achieving access to justice and suggestions were made to also include "inequities in ability to afford good legal representation" and those disadvantaged by a lack of information about law to adequately navigate within the justice system, especially pro se parties.

\section{B. Beliefs About Promoting Access to Justice}

Survey participants were asked to indicate whether they agreed with statements we provided that related to the administration of, and access to, justice in the family courts. These statements were drawn from the various reports written about access to justice. ${ }^{25}$ Beliefs about access to justice have been categorized into four separate but related clusters: 1) case management; 2) services; 3) children's involvement; and 4) professional collaboration.

It is important to understand the level of agreement regarding these beliefs because underlying, often unarticulated, disagree-

25 Access to Justice Task Force, supra note 1; Family Justice Reform, supra note 1; Justice Access Plan, supra note 1; Manitoba Bar Association, supra note 1; Sossin, supra note 1 . 
ments can create obstacles in developing strategies for best addressing access to justice issues. Tables 1-4 provide the list of statements, the corresponding percentages of agreement for the total sample, and the statistical result based on whether there were any reported differences across professional groups (lawyers, judges, dispute resolution professionals, evaluators, administrators, and mental health professionals). We completed separate analyses to compare results for legal, dispute resolution and mental health professionals, and also for any differences between the public and private sectors.

\section{Case Management}

Case management includes practices and procedures that can impact the process and flow of cases moving through the justice system. Several case management procedures have been suggested to help improve access to justice, including screening for conflict, screening for domestic violence, and fast tracking high conflict and complex cases

\section{i. Screening Case for Conflict}

Screening cases based on the risk factors associated with higher levels of conflict has gained considerable attention in the literature. ${ }^{26}$ The results show that the majority of participants supported screening for conflict and referring clients to appropriate services that best meet their needs based on the level of conflict (92.1\% either strongly agreed or agreed). ${ }^{27}$ These results appear to provide overwhelming support for developing procedures and measures for early assessment of conflict to better identify the needs of the families who use family law services.

\section{ii. Screening for Domestic Violence}

Due to the higher risk of violence during the separation process, scholars, policymakers, and practitioners have urged that all child custody cases should be screened for the presence of violence. ${ }^{28}$ Results from the survey strongly support this suggestion, as $86.3 \%$ of the participants either strongly agreed or agreed that

\footnotetext{
26 Salem, supra note 17.

27 See infra Table 1.

28 William G. Austin \& Leslie M. Drozd, Intimate Partner Violence and Child Custody Evaluation, Part I: Theoretical Framework, Forensic Model, and Assessment Issues, 9 J. Child CusTODY 250 (2012).
} 
all cases should be screened for domestic violence. This was consistent across professional groups. ${ }^{29}$

\section{iii. Fast Tracking High Conflict Cases}

Another key consideration proposed in the literature to better address the needs of high conflict families is to fast track their cases to court so that they appear in front of a judge earlier. ${ }^{30}$ But despite the critical need for differentiating and responding to high conflict families involved in the court system, very few services have been developed specifically for this population. The study shows mixed results about whether respondents agreed that high conflict cases should be fast tracked to court. ${ }^{31}$ This may be related to the lack of tools and services to assist the courts with these complex cases.

\section{iv. Complex Cases Sent to Court}

Scholars have suggested that there is a need for the court to focus on more complex cases while using out of court services to resolve others. ${ }^{32}$ Although the definition of complex case varies (e.g. complicated financial issues, presence of multiple risk factors in the case, etc.), there is a growing sentiment of the value of differentiating a case based on the complexity of the factors included. Similar to triaging high conflict families to court, results suggest that professionals also have differing opinions about limiting the court to addressing only complex cases and diverting others to out of court processes. Legal professionals (lawyers and judges) were less supportive of this approach than non-legal professionals, ${ }^{33}$ suggesting a potentially important difference in perspective related to case management concerns.

29 See infra Table 1.

30 Rachel Birnbaum \& Michael Saini, A Pilot Study to Establish Reliability and Validity: The Dimensions of Conflict in Separated Families, 51 Ontario Ass'N Children's Aid Soc'y 23 (2007).

31 See infra Table 1.

32 Salem, supra note 17.

33 See infra Table 1. 


\section{Table 1 - Case Management / Triage}

\begin{tabular}{|c|c|c|c|c|c|c|c|}
\hline Belief Statements & $\begin{array}{l}\text { Professional } \\
\text { Group }\end{array}$ & $\begin{array}{c}\text { Strongly } \\
\text { Agree }\end{array}$ & Agree & Neutral & Disagree & $\begin{array}{l}\text { Strongly } \\
\text { Disagree }\end{array}$ & Statistic \\
\hline \multirow{7}{*}{$\begin{array}{l}\text { Parties should be } \\
\text { screened for conflict } \\
\text { and referred to } \\
\text { services that best } \\
\text { meet their needs } \\
\text { (e.g. triage). }\end{array}$} & Lawyer & \begin{tabular}{|l|}
55.5 \\
\end{tabular} & 34.5 & 6.4 & 2.7 & \begin{tabular}{|l|}
0.9 \\
\end{tabular} & \multirow{7}{*}{$\begin{array}{l}X^{2}(20, \\
N=366) \\
=18.378 \\
p=.56\end{array}$} \\
\hline & Judge & 52.2 & 42.0 & 2.9 & 1.4 & 1.4 & \\
\hline & DR & 71.7 & 18.9 & 7.5 & 1.9 & 0.0 & \\
\hline & Evaluator & 62.1 & 28.8 & 3.0 & 3.0 & 3.0 & \\
\hline & Administrator & 72.5 & 22.5 & 5.0 & 0.0 & 0.0 & \\
\hline & MHP & 60.7 & 35.7 & 3.6 & 0.0 & 0.0 & \\
\hline & Total & 60.7 & 31.4 & 4.9 & 1.9 & 1.1 & \\
\hline \multirow{7}{*}{$\begin{array}{l}\text { All cases should be } \\
\text { screened for } \\
\text { domestic violence. }\end{array}$} & Lawyer & 56.6 & 27.9 & 9.0 & 1.8 & 4.5 & \multirow{7}{*}{$\begin{array}{l}X^{2}(20, \\
N=366) \\
=27.096 \\
p=.13\end{array}$} \\
\hline & Judge & 52.2 & 27.5 & 14.5 & 5.8 & 0.0 & \\
\hline & DR & 77.4 & 9.4 & 9.4 & 3.8 & 0.0 & \\
\hline & Evaluator & 61.5 & 26.2 & 9.2 & 1.5 & 1.5 & \\
\hline & Administrator & 72.5 & 22.5 & 2.5 & 2.5 & 0.0 & \\
\hline & MHP & 67.9 & 25.0 & 3.6 & 3.6 & 0.0 & \\
\hline & Total & 62.3 & 24.0 & 9.0 & 3.0 & 1.6 & \\
\hline \multirow{7}{*}{$\begin{array}{l}\text { High conflict cases } \\
\text { should be fast } \\
\text { tracked to litigation. }\end{array}$} & Lawyer & 24.5 & 18.2 & 15.5 & 29.1 & 12.7 & \multirow{7}{*}{$\begin{array}{l}X^{2}(20, \\
N=365) \\
=18.774 \\
p=.54\end{array}$} \\
\hline & Judge & 24.6 & 23.2 & 21.7 & 23.2 & 7.2 & \\
\hline & ADR & 20.8 & 13.2 & 22.6 & 30.2 & 13.2 & \\
\hline & Evaluator & 20.0 & 20.0 & 26.2 & 26.2 & 7.7 & \\
\hline & Administrator & 15.0 & 15.0 & 10.0 & 42.5 & 17.5 & \\
\hline & MHP & 25.0 & 28.6 & 10.7 & 21.4 & 14.3 & \\
\hline & Total & 22.2 & 28.6 & 10.7 & 21.4 & 14.3 & \\
\hline \multirow{7}{*}{$\begin{array}{l}\text { Only the most } \\
\text { complex cases } \\
\text { should be sent to } \\
\text { court to resolve } \\
\text { disputes. All other } \\
\text { cases should be } \\
\text { resolved outside of } \\
\text { the court system. }\end{array}$} & Lawyer & 6.4 & 12.7 & 11.8 & 45.5 & 23.6 & \multirow{7}{*}{$\begin{array}{l}X^{2}(20, \\
N=364) \\
=56.024, \\
p=.00 * *\end{array}$} \\
\hline & Judge & 8.7 & 11.6 & 26.1 & 47.8 & 5.8 & \\
\hline & DR & 9.4 & 28.3 & 18.9 & 30.2 & 13.2 & \\
\hline & Evaluator & 6.2 & 29.2 & 26.2 & 27.7 & 10.8 & \\
\hline & Administrator & 10.3 & 35.9 & 17.9 & 30.8 & 5.1 & \\
\hline & MHP & 14.3 & 42.9 & 25.0 & 17.9 & 0.0 & \\
\hline & Total & 8.2 & 22.5 & 19.8 & 36.8 & 12.6 & \\
\hline
\end{tabular}

For $\mathrm{p}$ values, see infra Appendix A.

\section{Services}

As part of the overall access to justice framework, there is growing emphasis on providing alternative services so that all families receive effective and affordable assistance that may limit their reliance on the courts. ${ }^{34}$ Several key services that have been introduced across court jurisdictions include: mandatory parent education, mandatory mediation, mediation for specialized needs, and unbundling services for limited legal representation. 


\section{i. Mandatory Parent Education}

Parent education programs are considered to be an important part of delivering access to justice. They enhance parental awareness about the importance of the needs of the children and the value of alternative dispute resolution approaches for reaching custody and support agreements. Several studies have documented the benefits of parent education programs,${ }^{35}$ and the adoption of mandatory parent education programs is widespread. ${ }^{36}$ The majority of respondents either strongly agreed or agreed $(86.4 \%)$ that parent education should be mandatory for all parents prior to court involvement. ${ }^{37}$ Some differences among professionals were noted, however, with mental health professionals and dispute resolution professionals more likely to strongly agree that mandatory parent education should be available for all parents prior to court involvement than legal professionals $\left(\mathrm{X}^{2}(8, \mathrm{~N}=366)=15.797, \mathrm{p}<.05\right)$. There was no significant difference between professionals in the public or private sectors.

\section{ii. Outside Services}

There is a growing movement to develop services outside of the courts (information, education, support) to help parties make better decisions regarding their disputes, while limiting their dependency on the courts to resolve their differences. Results show strong support for developing additional services for families before they attend the courts to resolve their disputes $(89.3 \%$ either strongly agree or agree across professional groups). ${ }^{38}$

\section{iii. Mandatory Mediation}

Mediation has perhaps been the most popular and widely adopted dispute resolution method in family law, in an effort to encourage parents to collaborate in making decisions about their separation and divorce, especially regarding minor children. ${ }^{39} \mathrm{Me}-$

35 Amanda Sigal et al., Do Parent Education Programs Promote Healthy Postdivorce Parenting? Critical Distinctions and a Review of the Evidence, 49 FAм. Cт. Rev. 120 (2011); Tamara A. Fackrell et al., How Effective Are Court-Affiliated Divorcing Parent Education Programs? A Meta-Analytic Study, 49 FAM. CT. REv. 107 (2011).

36 Susan L. Pollet \& Melissa Lombreglia, A Nationwide Survey of Mandatory Parent Education, 46 FAM. CT. Rev. 375 (2008).

37 See infra Table 2.

38 Id.

39 Ann Milne et al., The Evolution of Divorce and Family Mediation: An Overview, in DIvorce and Family Mediation: Models, Techniques, and Applications 3 (Jay Folberg et al. eds., 2004). 
diation is often administered in a voluntary fashion, requiring the agreement of both parties and can be ceased at any time. However, many jurisdictions have implemented mandatory mediation, which requires parties, by statute or procedural rule, to attend mediation prior to having their case heard in court. ${ }^{40}$ Results show that the majority of participants favoring mandatory mediation $(66.9 \%)$ either strongly agreed or agreed. Dispute resolution professionals and mental health professionals were more likely to strongly agree with mandatory mediation than legal professionals $\left(\mathrm{X}^{2}(8, \mathrm{~N}=365)=19.547, \mathrm{p}<.05\right) .{ }^{41}$ Professionals in the public sector were also more likely to strongly agree that mediation should be mandatory than respondents from the private sector $\left(\mathrm{X}^{2}(4\right.$, $\mathrm{N}=283)=13.543, \mathrm{p}<.05)$.

\section{iv. Mediation and Domestic Violence}

Whether to mediate parenting time disputes when there are allegations of domestic violence has been debated for more than three decades. Opponents of mediation in these cases focus on safety, fairness, effectiveness, and power imbalance. ${ }^{42}$ Proponents have suggested that mediation has the potential to be more effective and they have argued that the same risk factors that compromise safety can also be present in the traditional adversarial court process. ${ }^{43}$ Based on the results of this survey, the debate as to whether mediation should be offered to families when one party reports domestic violence remains unresolved. While some strongly agreed or agreed with the statement that mediation should not be offered $(21.3 \%)$, the majority $(64.4 \%)$ of respondents believed that mediation should be offered (i.e., they disagreed or strongly disagreed with the statement). ${ }^{44}$ There were minor differences across professionals. Dispute resolution professionals were more supportive of offering mediation for cases of domestic violence than judges

40 Nancy A. Welsh, Making Deals in Court-Connected Mediation: What's Justice Got to Do with It?, 79 WAsh. U. L.Q. 787 (2001); Nancy Thoennes et al., Mediation and Domestic Violence: Current Policies and Practices, 33 Fam. CT. Rev. 6 (1995).

41 See infra Table 2.

42 Barbara J. Hart, Gentle Jeopardy: The Further Endangerment of Battered Women and Children in Custody Mediation, 7 Mediation Q. 317 (1990); Thoennes, supra note 40.

43 René L. Rimelspach, Mediating Family Disputes in a World with Domestic Violence: How to Devise a Safe and Effective Court-Connected Mediation Program, 17 Oніо St. J. ON Disp. Resol. 95 (2001); Nancy Ver Steegh, Yes, No, and Maybe: Informed Decision Making about Divorce Mediation in the Presence of Domestic Violence, 9 WM. \& MARY J. WoMEN \& L. 145 (2003).

44 See infra Table 2. 
$\left(\mathrm{X}^{2}(20, \mathrm{~N}=366)=35.726, \mathrm{p}<.05\right)$. We found no differences between the beliefs of those in private and public sectors.

\section{v. Unbundling Services}

Unbundling legal services, also known as a limited scope representation, provides legal services for a specific component of a legal matter, which may include: confidential drafting assistance; negotiation coaching; making limited appearances in court; and providing legal information and advice. ${ }^{45}$ Unbundling is growing and has been popular in many jurisdictions; however, our results suggest that many participants are neutral $(38.7 \%)$ about the practice, ${ }^{46}$ possibly suggesting that more education is needed regarding the potential benefits and challenges of using this approach to provide legal services to clients unable to afford representation or who do not qualify for legal aid. Legal professionals were more likely to disagree with unbundling compared to dispute resolution and mental health professionals $\left(\mathrm{X}^{2}(4, \mathrm{~N}=345)=15.116, \mathrm{p}<.05\right)$.

45 Forrest S. Mosten, Unbundled Services to Enhance Peacemaking for Divorcing Families, 53 Fam. CT. Rev. 439 (2015).

46 See infra Table 2. 


\section{Table 2 - Access to Services}

\begin{tabular}{|c|c|c|c|c|c|c|c|}
\hline Belief Statement & $\begin{array}{c}\text { Professional } \\
\text { Group }\end{array}$ & $\begin{array}{c}\text { Strongly } \\
\text { Agree }\end{array}$ & Agree & Neutral & Disagree & $\begin{array}{l}\text { Strongly } \\
\text { Disagree }\end{array}$ & Statistic \\
\hline \multirow{7}{*}{$\begin{array}{l}\text { Parent Education } \\
\text { should be mandatory } \\
\text { for all parents prior } \\
\text { to court } \\
\text { involvement. }\end{array}$} & Lawyer & 55.0 & 25.2 & 9.9 & 6.3 & 3.6 & \multirow{7}{*}{$\begin{array}{l}X^{2}(20 \\
N=367) \\
=31.316 \\
p=.05^{*}\end{array}$} \\
\hline & Judge & 49.3 & 40.6 & 5.8 & 2.9 & 1.4 & \\
\hline & DR & 69.8 & 22.6 & 5.7 & 1.9 & 0.0 & \\
\hline & Evaluator & 59.1 & 25.8 & 9.1 & 0.0 & 6.1 & \\
\hline & Administrator & 57.5 & 27.5 & 12.5 & 2.5 & 0.0 & \\
\hline & MHP & 85.7 & 10.7 & 3.6 & 0.0 & 0.0 & \\
\hline & Total & 59.4 & 27.0 & 8.2 & 3.0 & 2.5 & \\
\hline \multirow{7}{*}{$\begin{array}{l}\text { Additional services } \\
\text { outside of the court } \\
\text { (information, } \\
\text { education, support) } \\
\text { should be offered to } \\
\text { families prior to } \\
\text { their involvement } \\
\text { with the courts. }\end{array}$} & Lawyer & 43.2 & 42.3 & 10.8 & 3.6 & 0.0 & \multirow{7}{*}{$\begin{array}{l}X^{2}(20 \\
N=367) \\
=24.858 \\
p=.20\end{array}$} \\
\hline & Judge & 43.5 & 43.5 & 11.6 & 1.4 & 0.0 & \\
\hline & DR & 60.4 & 30.2 & 5.7 & 1.9 & 1.9 & \\
\hline & Evaluator & 56.1 & 36.4 & 6.1 & 1.5 & 0.0 & \\
\hline & Administrator & 47.5 & 45.0 & 5.0 & 2.5 & 0.0 & \\
\hline & MHP & 78.6 & 17.9 & 3.6 & 0.0 & 0.0 & \\
\hline & Total & 51.2 & 38.1 & 8.2 & 2.2 & 0.3 & \\
\hline \multirow{7}{*}{$\begin{array}{l}\text { Mediation should be } \\
\text { mandatory for all } \\
\text { parties prior to court } \\
\text { involvement. }\end{array}$} & Lawyer & 31.5 & 28.8 & 8.1 & 15.3 & 16.2 & \multirow{7}{*}{$\begin{array}{l}X^{2}(20, \\
N=366) \\
=61.844, \\
p=.00 * *\end{array}$} \\
\hline & Judge & 34.8 & 23.2 & 24.6 & 17.4 & 0.0 & \\
\hline & DR & 50.9 & 34.0 & 5.7 & 1.9 & 7.5 & \\
\hline & Evaluator & 31.8 & 39.4 & 16.7 & 7.6 & 4.5 & \\
\hline & Administrator & 23.1 & 38.5 & 25.6 & 12.8 & 0.0 & \\
\hline & MHP & 60.7 & 17.9 & 10.7 & 7.1 & 3.6 & \\
\hline & Total & 36.3 & 30.6 & 14.5 & 11.5 & 7.1 & \\
\hline \multirow{7}{*}{$\begin{array}{l}\text { Mediation should } \\
\text { not be offered to } \\
\text { families when one } \\
\text { party reports } \\
\text { domestic violence. }\end{array}$} & Lawyer & 9.9 & 9.9 & 12.6 & 52.3 & 15.3 & \multirow{7}{*}{$\begin{array}{l}X^{2}(20, \\
N=366) \\
=35.726 \\
p=.01 *\end{array}$} \\
\hline & Judge & 14.5 & 11.6 & 18.8 & 50.7 & 4.3 & \\
\hline & DR & 5.7 & 11.3 & 7.5 & 43.4 & 32.1 & \\
\hline & Evaluator & 9.1 & 18.2 & 13.6 & 43.9 & 15.2 & \\
\hline & Administrator & 5.1 & 2.6 & 17.9 & 46.2 & 28.2 & \\
\hline & MHP & 3.6 & 25.0 & 17.9 & 39.3 & 14.3 & \\
\hline & Total & 9.0 & 12.3 & 14.2 & 47.5 & 16.9 & \\
\hline \multirow{7}{*}{$\begin{array}{l}\text { Unbundling services } \\
\text { should be offered to } \\
\text { all clients. }\end{array}$} & Lawyer & 21.8 & 23.6 & 30.0 & 15.5 & 9.1 & \multirow{7}{*}{$\begin{array}{l}X^{2}(20 \\
N=359) \\
=51.721 \\
p=.00 * *\end{array}$} \\
\hline & Judge & 26.9 & 28.4 & 43.3 & 1.5 & 0.0 & \\
\hline & DR & 19.2 & 28.8 & 46.2 & 5.8 & 0.0 & \\
\hline & Evaluator & 12.5 & 29.7 & 51.6 & 1.6 & 4.7 & \\
\hline & Administrator & 28.9 & 39.5 & 26.3 & 5.3 & 0.0 & \\
\hline & MHP & 32.1 & 32.1 & 35.7 & 0.0 & 0.0 & \\
\hline & Total & 22.3 & 28.7 & 38.7 & 6.7 & 3.6 & \\
\hline
\end{tabular}

\section{Children's Involvement}

There is a growing emphasis on equitable access to justice for children and creating approaches that better capture their views 
and preferences. ${ }^{47}$ As Butler, Scanlon, Robinson, Douglas, and Murch note: "[c]hildren do not experience their parents' divorce passively. Their involvement is an active, creative, and resourceful one. Recognizing children as competent (as well as relevant) witnesses to the process of family dissolution may further assist the process whereby their accounts are attended to and valued." 48

Several key initiatives have been attempted to provide for improved representation of views of children, recognize their legal rights, and provide them with services to help them successfully adjust to the family breakdown. These include children's legal representation and judicial interviews.

\section{i. Children's Legal Representation}

Most children interviewed in prior studies support having their views represented in the courts. ${ }^{49}$ The results of this study, however, show a mixed perception about whether all children involved with the courts should be offered a lawyer to represent their views ${ }^{50}$ irrespective of their professional affiliations, and there was no difference noted between the public and private sectors.

\section{ii. Judicial Interviews}

While not common across all jurisdictions, there has been increasing interest in judicial interviews of children. ${ }^{51}$ Studies have reported that children in custody disputes often want the opportunity to speak with a judge about their views and preferences. ${ }^{52}$ Our survey respondents were mixed about whether all children should be given the opportunity to speak with the judge, in accordance with the age and maturity of the child. ${ }^{53}$ Lawyers were more likely to strongly disagree than any other professional group, while judges were more likely to strongly agree $\left(\mathrm{X}^{2}(20, \mathrm{~N}=366)=29.559\right.$,

47 Birnbaum, supra note 22.

48 Ian Butler et al., Children's Involvement in their Parents' Divorce: Implications for Practice, 16 CHILd. \& Soc'y 89, 99 (2002).

49 Rachel Birnbaum et al., Children's Experiences with Family Justice Professionals and Judges in Ontario and Ohio, 25 InT'L J. L. PoL'y Fam. 398 (2011); Judy Cashmore \& Patrick Parkinson, Children's and Parents' Perceptions on Children's Participation in Decision Making after Parental Separation and Divorce, 46 FAM. CT. REv. 91 (2008).

50 See infra Table 3.

51 Birnbaum, supra note 22.

52 Birnbaum, supra note 22; Tamar Morag et al., Child Participation in the Family CourtsLessons from the Israeli Pilot Project, 26 InT'L J. L. PoL'y FAM. 1 (2012); Patrick Parkinson et al., Parents' and Children's Views on Talking to Judges in Parenting Disputes in Australia, 21 INT'L L. POL'y FAM. 84 (2007).

53 See infra Table 3. 
$\mathrm{p}<.05$ ), suggesting differences in perceptions about the potential costs and benefits of judicial interviews across professional groups. Professionals in the public sector were more likely to agree with judicial interviews than those in the private sector $\left(\mathrm{X}^{2}(4, \mathrm{~N}=352)=\right.$ 16.010, $\mathrm{p}<.05)$.

\section{TABle 3 - Children's Involvement}

\begin{tabular}{|c|c|c|c|c|c|c|c|}
\hline Belief Statement & $\begin{array}{l}\text { Professional } \\
\text { Group }\end{array}$ & $\begin{array}{c}\text { Strongly } \\
\text { Agree }\end{array}$ & Agree & Neutral & Disagree & $\begin{array}{l}\text { Strongly } \\
\text { Disagree }\end{array}$ & Statistic \\
\hline \multirow{7}{*}{$\begin{array}{l}\text { All children } \\
\text { involved with the } \\
\text { courts should be } \\
\text { offered a lawyer to } \\
\text { represent his/her } \\
\text { views. }\end{array}$} & Lawyer & 12.6 & 11.7 & 23.4 & 34.2 & 18.0 & \multirow{7}{*}{$\begin{array}{l}X^{2}(20, \\
N=366) \\
=17.563, \\
p=.61\end{array}$} \\
\hline & Judge & 13.2 & 17.6 & 22.1 & 35.3 & 11.8 & \\
\hline & DR & 9.4 & 9.4 & 32.1 & 39.6 & 9.4 & \\
\hline & Evaluator & 13.6 & 10.6 & 28.8 & 31.8 & 15.2 & \\
\hline & Administrator & 10.0 & 15.0 & 17.5 & 40.0 & 17.5 & \\
\hline & MHP & 7.1 & 32.1 & 25.0 & 28.6 & 7.1 & \\
\hline & Total & 11.7 & 14.2 & 24.9 & 35.0 & 14.2 & \\
\hline \multirow{7}{*}{$\begin{array}{c}\text { In contested cases, } \\
\text { all children should } \\
\text { be given the } \\
\text { opportunity to } \\
\text { speak with the } \\
\text { Judge in accordance } \\
\text { with the age and } \\
\text { maturity of the } \\
\text { child. }\end{array}$} & Lawyer & 7.2 & 56.8 & 10.8 & 0.0 & 25.2 & \multirow{7}{*}{$\begin{array}{l}X^{2}(20, \\
N=366) \\
=29.559 \\
p=.05^{*}\end{array}$} \\
\hline & Judge & 18.8 & 55.1 & 18.8 & 0.0 & 7.2 & \\
\hline & DR & 5.7 & 62.3 & 22.6 & 0.0 & 9.4 & \\
\hline & Evaluator & 10.8 & 50.8 & 20.0 & 1.5 & 16.9 & \\
\hline & Administrator & 5.0 & 62.5 & 17.5 & 0.0 & 15.0 & \\
\hline & MHP & 7.1 & 50.0 & 21.4 & 0.0 & 21.4 & \\
\hline & Total & 9.6 & 56.3 & 17.2 & 0.3 & 16.7 & \\
\hline
\end{tabular}

\section{Collaboration Among Professionals}

There is overwhelming support for collaboration among both legal and non-legal professionals in order to achieve the goals of access to justice; however, dispute resolution and mental health professionals were more likely to strongly agree with the need for collaboration than legal professionals $\left(\mathrm{X}^{2}(20, \mathrm{~N}=366)=31.623\right.$, $\mathrm{p}$ $<.05)$. No difference was found between the public and private sectors. ${ }^{54}$ 
TAble 4 - Collaborating Among BOTH LEgAl AND NONLEGAL PROFESSIONALS IS NEEDED

\begin{tabular}{|c|c|c|c|c|c|c|c|}
\hline Belief Statement & $\begin{array}{l}\text { Professional } \\
\text { Group }\end{array}$ & $\begin{array}{c}\text { Strongly } \\
\text { Agree }\end{array}$ & Agree & Neutral & Disagree & $\begin{array}{l}\text { Strongly } \\
\text { Disagree }\end{array}$ & Statistic \\
\hline \multirow{7}{*}{$\begin{array}{c}\text { For Access to } \\
\text { Justice to succeed, } \\
\text { collaboration among } \\
\text { both legal and non- } \\
\text { legal professionals is } \\
\text { needed. }\end{array}$} & Lawyer & 59.1 & 29.1 & 5.5 & 2.7 & 3.6 & \multirow{7}{*}{$\begin{array}{l}X^{2}(20, \\
N=366) \\
=31.623, \\
p=.04 *\end{array}$} \\
\hline & Judge & 56.5 & 33.3 & 4.3 & 5.8 & 0.0 & \\
\hline & DR & 73.6 & 22.6 & 3.8 & 0.0 & 0.0 & \\
\hline & Evaluator & 69.7 & 28.8 & 1.5 & 0.0 & 0.0 & \\
\hline & Administrator & 80.0 & 17.5 & 2.5 & 0.0 & 0.0 & \\
\hline & MHP & 85.7 & 14.3 & 0.0 & 0.0 & 0.0 & \\
\hline & Total & 66.9 & 26.5 & 3.6 & 1.9 & 1.1 & \\
\hline
\end{tabular}

\section{Access to Justice Priorities}

Given the paucity of resources available to family courts and related programs, there are clearly limitations to addressing access to justice issues. We therefore asked respondents to rank various priorities from one (most important) to ten (least important). A lower mean is related to higher importance. Table 5 presents the aggregated rankings.

\section{Table 5 - Rank Order of Priorities for Access to JustiCE}

\begin{tabular}{|l|r|r|r|}
\hline Item & $\mathrm{R}$ & $\mathrm{M}$ & $\mathrm{SD}$ \\
\hline Reducing family conflict & 1 & 3.87 & 2.682 \\
\hline Quicker resolution of disputes & 2 & 4.48 & 2.462 \\
\hline Timely access to alternative dispute resolution & 3 & 4.57 & 2.515 \\
\hline Improving children's adjustment post separation & 4 & 4.77 & 2.747 \\
\hline Improved services for self-represented litigants & 5 & 5.33 & 3.062 \\
\hline Increased protection against domestic violence & 6 & 5.84 & 2.590 \\
\hline Easier access to court/judicial hearings & 7 & 5.88 & 2.994 \\
\hline Increased services for marginalized populations & 8 & 5.99 & 2.697 \\
\hline Reducing court cost for families & 9 & 6.32 & 2.520 \\
\hline Reducing litigation rates & 10 & 7.34 & 2.654 \\
\hline
\end{tabular}

Note: $\mathrm{R}=$ Rank of importance; $\mathrm{M}=$ Mean; $\mathrm{SD}=$ Standard Deviation 
Across all professions, reducing family conflict was rated as the most important priority of access to justice, followed by quicker resolution of disputes, timely access to alternative dispute resolution, and improving children's adjustment post separation. The middle range of priorities included improved services for self-represented litigants, increased protection against domestic violence, easier access to court/judicial hearings, and increased services for marginalized populations. Interestingly, reducing court cost for families, and reducing litigation rates were reported as the least important priorities of access to justice.

\section{Rank Order of Priorities by Primary Profession}

To better understand the concerns of different stakeholders we examined priorities by profession (lawyers, judges, dispute resolution professionals, evaluators, administrators, and mental health professionals). Table 6 shows priorities by profession categorized as high, moderate, and low, and is presented without statistical information for ease of comparison. Table 15 (Appendix A) presents the percentages and statistical findings.

\section{TAble 6 - Priorities by Profession}

\begin{tabular}{|c|c|c|c|c|c|c|}
\hline & Lawyers & Judges & Dispute Res. & Evaluators & Admin. & MHP \\
\hline $\mathrm{H}$ & $\begin{array}{l}\text { Reduce } \\
\text { conflict } \\
\text { Quicker } \\
\text { resolution } \\
\text { Timely ADR }\end{array}$ & $\begin{array}{l}\text { Reduce } \\
\text { conflict } \\
\text { Services for } \\
\text { SRLs } \\
\text { Quicker } \\
\text { resolution } \\
\text { Timely ADR }\end{array}$ & $\begin{array}{l}\text { Reduce } \\
\text { conflict } \\
\text { Timely ADR } \\
\text { Child } \\
\text { adjustment } \\
\text { Quicker } \\
\text { resolution }\end{array}$ & $\begin{array}{l}\text { Reduce } \\
\text { conflict } \\
\text { Quicker } \\
\text { resolutions } \\
\text { Child } \\
\text { adjustment } \\
\text { Timely ADR }\end{array}$ & $\begin{array}{l}\text { Services for } \\
\text { SRLs } \\
\text { Timely ADR } \\
\text { Reduce } \\
\text { conflict } \\
\text { Quicker } \\
\text { resolution }\end{array}$ & $\begin{array}{l}\text { Reduce } \\
\text { conflict } \\
\text { Child } \\
\text { adjustment } \\
\text { Timely ADR } \\
\text { Quicker } \\
\text { resolution }\end{array}$ \\
\hline M & $\begin{array}{l}\text { Child } \\
\text { adjustment } \\
\text { Access to } \\
\text { hearings } \\
\text { Services for } \\
\text { SRLs } \\
\text { Reduce court } \\
\text { costs }\end{array}$ & $\begin{array}{l}\text { Child } \\
\text { adjustment } \\
\text { Services for } \\
\text { marginalized } \\
\text { pop } \\
\text { Protection } \\
\text { against } \\
\text { domestic } \\
\text { violence } \\
\text { Access to } \\
\text { hearings } \\
\end{array}$ & $\begin{array}{l}\text { Services for } \\
\text { SRLs } \\
\text { Protection } \\
\text { against } \\
\text { domestic } \\
\text { violence }\end{array}$ & $\begin{array}{l}\text { Protection } \\
\text { against } \\
\text { domestic } \\
\text { violence } \\
\text { Services for } \\
\text { marginalized } \\
\text { pop }\end{array}$ & $\begin{array}{l}\text { Child } \\
\text { adjustment } \\
\text { Protection } \\
\text { against } \\
\text { domestic } \\
\text { violence } \\
\text { Access to } \\
\text { hearings }\end{array}$ & $\begin{array}{l}\text { Reduce court } \\
\text { costs } \\
\text { Protection } \\
\text { against } \\
\text { domestic } \\
\text { violence }\end{array}$ \\
\hline $\mathrm{L}$ & \begin{tabular}{|l|} 
Protection \\
against \\
domestic \\
violence \\
Services for \\
marginalized \\
pop \\
Reduce \\
litigation \\
\end{tabular} & $\begin{array}{l}\text { Reduce court } \\
\text { costs } \\
\text { Reduce } \\
\text { litigation }\end{array}$ & $\begin{array}{l}\text { Services for } \\
\text { marginalized } \\
\text { pop } \\
\text { Reduce court } \\
\text { costs } \\
\text { Access to } \\
\text { hearings } \\
\text { Reduce } \\
\text { litigation }\end{array}$ & $\begin{array}{l}\text { Access to } \\
\text { hearings } \\
\text { Reduce court } \\
\text { costs } \\
\text { Services for } \\
\text { SRLs } \\
\text { Reduce } \\
\text { litigation }\end{array}$ & $\begin{array}{l}\text { Services for } \\
\text { marginalized } \\
\text { pop } \\
\text { Reduce court } \\
\text { costs } \\
\text { Reduce } \\
\text { litigation }\end{array}$ & $\begin{array}{l}\text { Access to } \\
\text { hearings } \\
\text { Services for } \\
\text { SRLs } \\
\text { Services for } \\
\text { marginalized } \\
\text { pop } \\
\text { Reduce } \\
\text { litigation }\end{array}$ \\
\hline
\end{tabular}

$\mathrm{H}=$ High Priority; $\mathrm{M}=$ Moderate Priority; $\mathrm{L}=$ Low Priority 
We found some significant group differences for the rankings of several priorities: (1) dispute resolution professionals prioritized reducing family conflict significantly more than lawyers, mental health professionals, and custody evaluators $(\mathrm{F}(25,344)=3.284$, p. $=.00) ;(2)$ mental health professionals were significantly more likely than lawyers and administrators to prioritize improving children's adjustment post-separation $(\mathrm{F}(5,342)=2.515$, p.=.03); (3) administrators were significantly more likely to prioritize improved services for self-represented litigants than lawyers, evaluators, dispute resolution, and mental health professionals $(\mathrm{F}(5,343)=5.415$, $\mathrm{p}=.03)$; (4) lawyers prioritized easier access to court/judicial hearings significantly more than dispute resolution professionals $(\mathrm{F}(5$, $335)=2.448, \mathrm{p}=.03)$; and (5) lawyers prioritized reducing court costs for families significantly more than judges $(\mathrm{F}(5,344)=3.284$, $\mathrm{p}=.00)$.

\section{Legal, Dispute Resolution and Mental Health Professionals' Priorities for Access to Justice}

We also examined priorities of the broader categories of legal, dispute resolution, and mental health professionals, hypothesizing that background and training help shape different priorities among those who work in the same system. Legal (e.g., lawyers, judges, administrators), dispute resolution (mediators, evaluators, parenting coordinators), and mental health professionals shared many of the same priorities, but some noteworthy differences were found. Legal professionals ranked the need for improved services for self represented litigants as a higher priority than dispute resolution and mental health professionals $(\mathrm{F}(2,342),=7.658$, p. $<.00)$. Legal professionals also ranked the need for easier access to court/ judicial hearings more important than dispute resolution and mental health professionals $(\mathrm{F}(2,335),=3.369$, p. $<.05)$. Perhaps not surprisingly, mental health professionals ranked the priority to improve children's adjustment post separation higher than legal professionals and dispute resolution professionals $(\mathrm{F}(2,339),=$ 5.981, p. <.00). In addition, dispute resolution and mental health professionals ranked the goal of reducing family conflict as a higher priority than their legal counterparts $(t(326),=2.542, \mathrm{p} .<$ $.05)$.

\section{Public vs. Private Priorities for Access to Justice}

Finally, we examined differences in priorities between those in the public and private sector. Respondents working in the public 
or court based services (e.g., court administrators, judges, courtbased mediators, and court-based evaluators) ranked the need for improved services for self-represented litigants significantly more highly than those in the private sector (lawyers, private custody evaluators, parenting coordinators) $(t(315),=-4.510, \mathrm{p} .<.00)$. Public sector respondents also ranked the need for increasing protection against domestic violence as more important than the private sector $(t(311),=-2.133, \mathrm{p} .<.05)$. In contrast, participants in the private sector ranked the need for timely access to alternative dispute resolution as more important than the public sector $(t$ $(317),=2.518, \mathrm{p} .<.05)$. Private for-profit sectors ranked reducing court cost for families more importantly than both the private notfor-profit sector and the public sector $(\mathrm{F}(2,343),=3.728, \mathrm{p} .<.05)$.

\section{Discussion}

Given the ongoing calls for family law reform ${ }^{55}$ and the recent focus on access to justice related reforms, ${ }^{56}$ it is critical that we understand the views of stakeholders involved. This study focused on the similarities and differences, including how access is defined and the beliefs and priorities of the stakeholders across the multiple disciplines involved in the family law arena. Although we were unable to survey those family members who use family courts, such studies have been conducted ${ }^{57}$ and any access to justice related reform efforts must understand and seriously consider these perspectives.

Results demonstrate that the overwhelming majority of respondents include legal and dispute resolution when defining access to justice and when considering their beliefs and priorities. The results of this survey further indicate that stakeholders support timely access to family court, easier access to court, alternatives to

55 Barbara A. Babb, Unified Family Courts: An Interdisciplinary Framework and a ProblemSolving Approach, in Problem Solving Courts 65-82 (2013); William J. Howe III \& Elizabeth Scully, Redesigning the Family Law System to Promote Healthy Families, 53 FAм. CT. Rev. 361 (2015).

56 Sossin, supra note 1.

57 Julie Macfarlane, THE NATIONAL SELF-REPRESENTED LITIGANTS PROJECT: IDENTIFYING AND MEETING THE NEEDS OF SELF-REPRESENTED LITIGANTS Convocation - Treasurer's Advisory Group on Access to Justice (TAG) Working Group Report (2013); Institute for the Advancement of the American Legal System, 2007 ColoRAdo Voter Opinions on the Judiciary (2007). 
family court to solve family law issues, and increased access to family law information.

\section{A. Definition of Access to Justice}

Our survey affirmed that there is strong agreement that the definition of access to justice goes beyond the courtroom and judges to include dispute resolution processes such as mediation; however, it also affirmed, on a much smaller scale, some disparate views of access to justice. As noted above, some believe that justice can only be attained in a court of law. There are also those who take a much broader approach, including one respondent who said, "I want to emphasize that today the purpose and responsibilities of courts must encompass access to programs and services that will lead to resolution of disputes that are related to the husbandwife, parent-child relationship." While the vast majority $(87 \%)$ agreed with our moderately inclusive definition, it is important to understand precisely what stakeholders mean when they refer to access to justice, as definitions may vary. An example comes from Canadian Supreme Court Justice Thomas Cromwell: "As one participant put it to me recently, sometimes access to justice is more about a bus pass or a baby sitter than it is about meeting with a judge." 58

\section{B. Beliefs}

Overall, we found solid agreement about many of the beliefs that are related to case management, services, and the involvement of children in access to justice initiatives. Importantly, there was overwhelming agreement across professions that, in order for efforts of access to justice to succeed, collaboration among legal and non-legal professionals is needed. There were also several significant differences, suggesting the need for further collaboration and cross-discipline dialogue on how to best achieve access to justice from an interdisciplinary perspective. Although these findings may seem obvious to professionals who work within multidisciplinary teams, understanding belief patterns across professionals can help

58 Thomas A. Cromwell, Remarks: PleAC Conference Toronto (2012). 
to improve teams by focusing on the potential obstacles for creating workable solutions for their clients.

Dispute resolution professionals were more likely to agree that all mediation cases should be screened for violence than any other group, while lawyers and judges were less likely to agree. Dispute resolution professionals also were more likely to support offering mediation in cases of domestic violence compared to judges. Lawyers were less likely to agree that unbundling legal services should be offered to all clients, and lawyers and judges were more likely to disagree with the statement that only the most complex cases should be sent to court, with others being resolved outside of court.

We believe, generally, that many of these beliefs simply reflect the respondents' professional backgrounds and experiences. For example, dispute resolution professionals have been trained to favor screening for domestic violence as model standards for mediators $^{59}$ and practice guidelines for parenting coordinators ${ }^{60}$ both encourage this practice. Lawyers may not support unbundled legal services because they may be concerned about possible pitfalls when compared to full representation, or because they may not be comfortable with a changing model for providing legal services. Additionally, dispute resolution professionals may encourage mediation in cases involving allegations of domestic violence because they may have had positive experiences in these matters while judges may be exercising caution based on their own experiences.

While the majority of respondents favored screening cases for conflict, domestic violence, and complexity, they differed about what to do with these cases once screening was completed. Respondents were divided as to whether high conflict cases should be fast tracked to litigation and whether the court should focus on complex cases, with lawyers and judges most likely to disagree with fast tracking. This is an important finding because it points to a lack of consensus about the best pathway for the most challenging cases. It may suggest that greater attention is needed to develop appropriate (perhaps out of court) interventions to address the needs of these high-risk families. One approach may be to develop services that include both the structure of the court (use of orders, restraining orders, and case management) and the support of dispute resolution or therapeutic services to assist in resolving the risk

59 Model Standards of Practice for Family and Divorce Mediation (AFCC 2001).

60 Guidelines for Parenting Coordination (AFCC 2005). 
factors that make these cases so complex. It is also possible, however, that these responses represent deep-seated philosophical differences about the role of the court, legal professionals, and nonlegal professionals in the family justice system, which have the potential to derail reform initiatives.

A number of initiatives have been proposed to improve access to justice, including both traditional legal procedures and additional dispute resolution services targeted to the needs of families. The results of the study clearly point to the overwhelming support of providing families with information and outside services prior to appearing in the courts. But not all professionals agree on how best to provide these services.

Although there is a growing emphasis on including the views and preferences of children within child custody disputes, we found that respondents had mixed opinions about whether these approaches should be offered to all children, or limited to specific children based on their circumstances of the case. The results may suggest a belief that there is a need to consider the unique aspects of each case, and the potential benefits and risks of actively involving children in the disputes.

\section{Priorities}

We found substantial agreement on priorities, but some respondent priorities differ according to professional backgrounds and primary affiliations. Although all professionals ranked reducing family conflict as their top priority, it should not be surprising that it is a greater priority for dispute resolution professionals, whose primary role it is to help resolve family conflict. By the same token, mental health professionals' priority of child adjustment post-separation, court administrators' focus on providing more services for SRLs (which potentially addresses court administration needs) and lawyers' prioritizing easier access to court hearings and reducing court costs (a benefit for their practice and for their clients) seem consistent with priorities associated with their profession.

Generally, we found that legal professionals' priorities were associated with a more efficient legal system, while mental health and dispute resolution professionals placed a higher priority on family wellbeing measures such as child adjustment and reducing conflict. For example, judges and administrators in particular place 
a higher priority on services for self-represented litigants, as they are most likely charged with the administrative task of addressing their needs and are most likely (with some lawyers) to interact with self-represented litigants.

Caution should be exercised in interpreting these results, as there are some priorities to which respondents might attribute more than one meaning. For example, reducing family conflict might be seen as a priority from a family wellbeing perspective, as increased conflict is known to have negative impact on children. Less family conflict may also facilitate settlement, however, resulting in fewer hearings and less judicial and court time for a particular case. The same might be true for quicker resolution of disputes. Further research is needed to better understand how these items were interpreted.

\section{Multidisciplinary Collaboration}

When considering an access to justice framework, it is important to recognize that different service users, approaching the courts with varying family court issues, will have vastly different needs. Several initiatives have been created to provide families with more information and increase access to alternative dispute resolution services and quicker and easier legal procedures; yet, many of these initiatives have been introduced as patchwork to solve specific challenges of access to justice rather than an overarching approach to address the various needs of families who come into contact with the justice system. The results of this paper demonstrate that, although there is much agreement among professionals in defining access to justice and prioritizing changes to the system, there are some important differences about the values and weight given to the various approaches. Awareness, understanding, and respect for the various perspectives about how best to meet the needs of families are important steps towards meaningful interdisciplinary dialogue. With effective interdisciplinary dialogue, these various perspectives may work in concert rather than compete for the limited resources available to assist families involved in family law matters.

According to Kourlis, Taylor, Shepard, and Pruett, professionals working in the field of family law should consider a hybrid model of service delivery that shares responsibilities between legal and non-legal services, rather than a dichotomy of legal and non- 
legal services, to best meet the needs of children and families accessing services to assist in resolving disputes. ${ }^{61}$ The authors propose that courts could continue to be responsible for the delivery of services that fulfill its core functions of fact finding, decision making, and enforcement, but with greater support and assistance from non-legal professionals to assist in the delivery of helping services such as education, alternative dispute resolution, and therapeutic supports. Developing such an integrated and interdisciplinary access to justice approach makes the most of scarce resources by matching services that best fit the multiple needs of families. Due to the increasing complexity of families, family law reform should move away from simple solutions for specific issues and consider an organized approach that includes a system level consideration of the most efficient and effective use of legal and community services. Given the unique needs of families who come into contact with the family court system, an integrated approach should screen for the unique differences of families accessing services and move towards a proportionality of legal and community services that best fit the differing needs of the families.

\section{E. Limitations}

Several limitations to the methodology used in the study warrant attention. An ideal sample in quantitative research designs involves the use of a random sample from a representative population to determine the validity and reliability of the findings. In this study, the sample was not random and, therefore, does not represent the population of all stakeholders involved in family law matters. It does, however, represent an experienced subset of family law professionals who are motivated to join professional associations and become active in reform and policy efforts. Another limitation of the methodology is associated with the source of the data. The study relied on self-report survey, so there is always the danger of reporting bias or error.

Although several initiatives related to legal representation were included in this study (e.g., unbundling, access to the courts, legal information, services for unrepresented litigants), questions specific to the access of full legal representation were not included

61 Rebecca Love Kourlis et al., IAALS' Honoring Families Initiative: Courts and Communities Helping Families in Transition Arising from Separation or Divorce (2013). 
in this analysis (e.g., access to private representation, Duty Counsel, Guardian ad litem services, pro-bono services, Pro Se Family Law Coordinator, etc.) as the focus of this study was to consider the priorities and beliefs that have been suggested in the reports about access to justice. Further research will need to consider the barriers, challenges, and opportunities for full legal representation.

\section{F. Future Research}

There is "surprisingly little empirical information ... about the adequacy of the justice system's response or the consequences of adequate or inadequate resolution of family disputes." ${ }_{2}$ The lack of systematic evaluations on the efficiency and effectiveness of access to justice initiatives is due partly to the lack of consensus of how best to define, measure, and assess effective services. The results of this study point to the priorities that should be included in effectiveness-based studies. Specifically, evaluating access to justice services should include outcome variables to measure the reduction of family conflict, the efficiency of services to resolve disputes, the timeliness and impact of dispute resolution services, the improvement of children's adjustment post separation, the experience of litigants, and the safety of families involved in these disputes. Long-term outcomes should ultimately measure whether services reduce litigation and court costs for families. Longitudinal studies are needed to track families as they progress through the various legal and community services to identify the services that best meet their needs and that are the most effective in resolving the issues that first brought them to the attention of the courts.

62 FAmily Justice Reform, supra note 1. 
Appendix A

Ranking of Priorities by Primary Profession

\begin{tabular}{|c|c|c|c|c|c|}
\hline Priority & $\begin{array}{l}\text { Professional } \\
\text { Group }\end{array}$ & WR & $\mathbf{M}$ & SD & Between Group \\
\hline \multirow{7}{*}{ Reducing family conflict } & Lawyer & 5 & 4.16 & 2.652 & \multirow{7}{*}{$\begin{array}{c}\mathrm{F}(5,344)=3.284 \\
\mathrm{p}=.00^{* *}\end{array}$} \\
\hline & Judge & 3 & 4.07 & 2.780 & \\
\hline & DR & 1 & 2.58 & 1.853 & \\
\hline & Evaluator & 4 & 4.10 & 2.650 & \\
\hline & Administrator & 6 & 4.33 & 3.115 & \\
\hline & MHP & 2 & 3.54 & 2.742 & \\
\hline & Total & & 3.87 & 2.682 & \\
\hline \multirow{7}{*}{ Quicker resolution of disputes } & Lawyer & 2 & 4.34 & 2.557 & \multirow{7}{*}{$\begin{array}{c}\mathrm{F}(5,349)=0.483 \\
\mathrm{p}=.78\end{array}$} \\
\hline & Judge & 4 & 4.63 & 2.447 & \\
\hline & DR & 5 & 4.73 & 2.580 & \\
\hline & Evaluator & 1 & 4.20 & 2.407 & \\
\hline & Administrator & 3 & 4.54 & 2.150 & \\
\hline & MHP & 6 & 4.81 & 2.546 & \\
\hline & Total & & 4.48 & 2.462 & \\
\hline \multirow{7}{*}{$\begin{array}{l}\text { Timely access to alternative } \\
\text { dispute resolution }\end{array}$} & Lawyer & 3 & 4.61 & 2.371 & \multirow{7}{*}{$\begin{array}{c}\mathrm{F}(5,345)=1.222 \\
\mathrm{p}=.298\end{array}$} \\
\hline & Judge & 5 & 4.81 & 2.533 & \\
\hline & DR & 2 & 4.06 & 2.307 & \\
\hline & Evaluator & 6 & 4.98 & 2.895 & \\
\hline & Administrator & 1 & 4.03 & 2.150 & \\
\hline & MHP & 4 & 4.62 & 2.899 & \\
\hline & Total & & 4.57 & 2.515 & \\
\hline \multirow{7}{*}{$\begin{array}{l}\text { Improving children's } \\
\text { adjustment post separation }\end{array}$} & Lawyer & 5 & 5.20 & 2.786 & \multirow{7}{*}{$\begin{array}{c}\mathrm{F}(5,342)=2,515 \\
\mathrm{p}=.03^{*}\end{array}$} \\
\hline & Judge & 4 & 5.02 & 2.697 & \\
\hline & DR & 2 & 4.11 & 2.305 & \\
\hline & Evaluator & 3 & 4.28 & 2.888 & \\
\hline & Administrator & 6 & 5.39 & 2.756 & \\
\hline & MHP & 1 & 3.93 & 2.688 & \\
\hline & Total & & 4.77 & 2.747 & \\
\hline \multirow{7}{*}{$\begin{array}{l}\text { Improved services for self- } \\
\text { represented litigants }\end{array}$} & Lawyer & 3 & 5.44 & 3.104 & \multirow{7}{*}{$\begin{array}{c}\mathrm{F}(5,343)=5.415 \\
\mathrm{p}=.00 * *\end{array}$} \\
\hline & Judge & 2 & 4.44 & 2.803 & \\
\hline & DR & 4 & 5.73 & 3.004 & \\
\hline & Evaluator & 5 & 6.27 & 2.982 & \\
\hline & Administrator & 1 & 3.71 & 2.609 & \\
\hline & MHP & 6 & 6.32 & 3.175 & \\
\hline & Total & & 5.33 & 3.062 & \\
\hline
\end{tabular}




\begin{tabular}{|c|c|c|c|c|c|}
\hline Priority & $\begin{array}{c}\text { Professional } \\
\text { Group }\end{array}$ & WR & $\mathbf{M}$ & SD & Between Group \\
\hline \multirow{7}{*}{ Reducing family conflict } & Lawyer & 5 & 4.16 & 2.652 & \multirow{7}{*}{$\begin{array}{c}\mathrm{F}(5,344)=3.284 \\
\mathrm{p}=.00 * *\end{array}$} \\
\hline & Judge & 3 & 4.07 & 2.780 & \\
\hline & DR & 1 & 2.58 & 1.853 & \\
\hline & Evaluator & 4 & 4.10 & 2.650 & \\
\hline & Administrator & 6 & 4.33 & 3.115 & \\
\hline & MHP & 2 & 3.54 & 2.742 & \\
\hline & Total & & 3.87 & 2.682 & \\
\hline \multirow{7}{*}{ Quicker resolution of disputes } & Lawyer & 2 & 4.34 & 2.557 & \multirow{7}{*}{$\begin{array}{c}\mathrm{F}(5,349)=0.483 \\
\mathrm{p}=.78\end{array}$} \\
\hline & Judge & 4 & 4.63 & 2.447 & \\
\hline & DR & 5 & 4.73 & 2.580 & \\
\hline & Evaluator & 1 & 4.20 & 2.407 & \\
\hline & Administrator & 3 & 4.54 & 2.150 & \\
\hline & MHP & 6 & 4.81 & 2.546 & \\
\hline & Total & & 4.48 & 2.462 & \\
\hline \multirow{7}{*}{$\begin{array}{l}\text { Timely access to alternative } \\
\text { dispute resolution }\end{array}$} & Lawyer & 3 & 4.61 & 2.371 & \multirow{7}{*}{$\begin{array}{c}\mathrm{F}(5,345)=1.222 \\
\mathrm{p}=.298\end{array}$} \\
\hline & Judge & 5 & 4.81 & 2.533 & \\
\hline & DR & 2 & 4.06 & 2.307 & \\
\hline & Evaluator & 6 & 4.98 & 2.895 & \\
\hline & Administrator & 1 & 4.03 & 2.150 & \\
\hline & MHP & 4 & 4.62 & 2.899 & \\
\hline & Total & & 4.57 & 2.515 & \\
\hline \multirow{7}{*}{$\begin{array}{l}\text { Improving children's } \\
\text { adjustment post separation }\end{array}$} & Lawyer & 5 & 5.20 & 2.786 & \multirow{7}{*}{$\begin{array}{c}\mathrm{F}(5,342)=2,515 \\
\mathrm{p}=.03^{*}\end{array}$} \\
\hline & Judge & 4 & 5.02 & 2.697 & \\
\hline & $\mathrm{DR}$ & 2 & 4.11 & 2.305 & \\
\hline & Evaluator & 3 & 4.28 & 2.888 & \\
\hline & Administrator & 6 & 5.39 & 2.756 & \\
\hline & MHP & 1 & 3.93 & 2.688 & \\
\hline & Total & & 4.77 & 2.747 & \\
\hline \multirow{7}{*}{$\begin{array}{l}\text { Improved services for self- } \\
\text { represented litigants }\end{array}$} & Lawyer & 3 & 5.44 & 3.104 & \multirow{7}{*}{$\begin{array}{c}\mathrm{F}(5,343)=5.415 \\
\mathrm{p}=.00 * *\end{array}$} \\
\hline & Judge & 2 & 4.44 & 2.803 & \\
\hline & DR & 4 & 5.73 & 3.004 & \\
\hline & Evaluator & 5 & 6.27 & 2.982 & \\
\hline & Administrator & 1 & 3.71 & 2.609 & \\
\hline & MHP & 6 & 6.32 & 3.175 & \\
\hline & Total & & 5.33 & 3.062 & \\
\hline
\end{tabular}

Note: $\mathrm{WR}=$ Ranking of goals among the six professional types; $\mathrm{M}=$ Mean; SD = Standard Deviation, Between Group = based on univariate analysis of the ranking of goals by professional type.

$*$ = significant at $\mathrm{p} .<.05$

$* *$ significant at $\mathrm{p} .<.01$ 